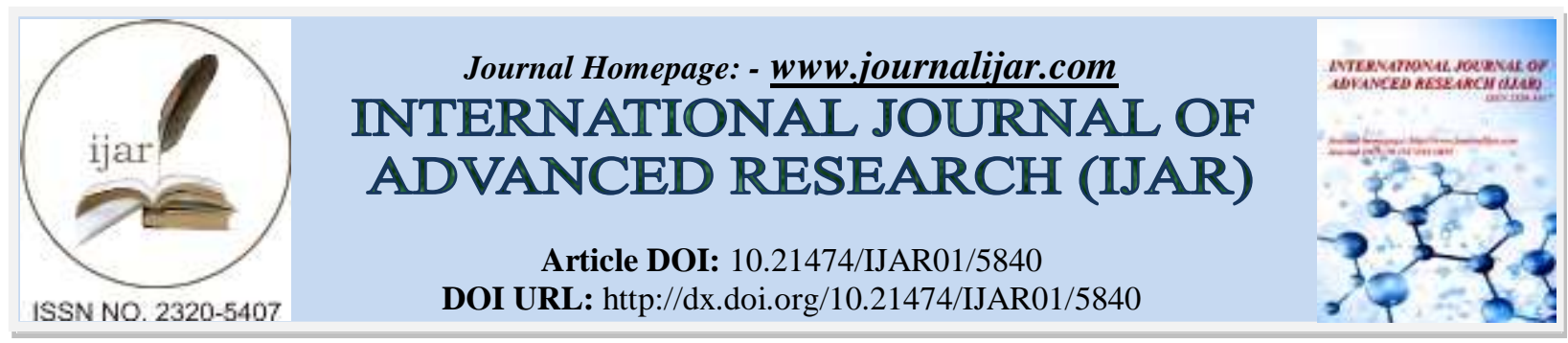

RESEARCH ARTICLE

\title{
THE ASSESMENT OF TAKE-OVER OPERATIONS IN CUSTOMS ENTREPOTS REGIME IN TERMS OF VALUE-ADDED TAX AND CORPORATION TAX.
}

\author{
Dr. Ceyda Kukrer.
}

\section{Manuscript Info}

(..........................

Manuscript History

Received: 12 September 2017

Final Accepted: 14 October 2017

Published: November 2017

Key words:-

Take-Over Operations In Customs

Entrepots, Customs Entrepots,

Cooparate Tax, Value Added Tax.

\section{Abstract}

As a natural consequence of the rule of subjecting customs transactions as a international trade, certain customs regimes must be applied. Customs Regimes are the most applicable facilaties to the Customs Certified Transactions or Uses. Acquired by fully responsible real persons and institutions bringing goods to Turkey within the context of customs entrepots and sell these goods by transferring them from the entrepots and acquire earnings are subject to taxation. The taxation of the income obtained at the time of the transfer of the goods to another company by issuing the invoice for the Customs VAT on customs is the problem of many foreign tradeers who will not be evaluated as the revenue gained from the sale. The article evaluated these points separately in terms of the Customs Legislation.

Copy Right, IJAR, 2017,. All rights reserved.

\section{Introduction:-}

In the 333th article of the Customs Regulation, it is stipulated that the sale or the transfer can be realized both domestically and abroad. Transit trade is the sale of goods purchased from abroad or customs entrepots to a resident firm or abroad, and it is also vital in facilitating economic transformation and regional trade, while contributing to the growth of employment, incomes and tax revenues [1]. This is not subject to the provisions of the import and export regime, as the goods do not free movement of goods regime (as they are not nationalized). Likewise, the sale of goods to another country by another company that takes over the goods in the customs entreports is a transit trade transaction. In other words, transit trade transactions also include operations where goods are transported from the foreign upstream supplier to a foreign customer through a domestic or abroad customs entrepots [2].

Since the imported goods are not in the customs territory or in the customs entrepots yet, they can be sold in the country by take-over operations. In this case, the importing company shall not sell the goods; if the company wishes to sell to a domestic company, the relevant transfer contracts, petitions and sales invoices of the transferor company can be made in the customs office, and the transferring company can start the import transactions after the transfer decision is made. The sales invoices are non-value added tax. Customs declarations shall be opened on behalf of the second or third buyer and the taxation obligation for imports shall pass to the party which has opened the declaration. The evaluation of the sale of goods imported from abroad or freight into the country through the transfer (non-national) without the introduction of free circulation in terms of Corporate Tax and Value Added Tax is explained in the following sections of our article. 


\section{Customs Entrepots Regime Definition and Regulatory Arrangements:-}

Customs Entrepots Regime is explained in Customs Code [3] 93-107. and 328-348 of the Customs Regulation [4]. It shows that the customs entrepots regime has a very wide range in our legislation. The Customs Entrepots Regime has emerged as a necessity arising from the requirements and applications related to the goods which are subject to the international trade.

Article 2 of the on Customs Law numbered 4458 and published in the Official Gazette dated 04.11.1999 and numbered 23866 (as amended the Law no:5911) states that the customs territory shall include the territorial waters, the inland maritime waters and the airspace of Turkey. On the other hand, it is stated under the Customs Entrepots Procedure topic of the same Law Article 93 that the customs entrepot procedure shall allow the storage in a customs entrepots of [5]:

1. The goods not in free circulation, without such goods being subject to import duties or commercial policy measures,

2. The goods in free circulation being placed in a customs entrepots shall attract the application of measures normally attaching to the export of such goods.

It is also stated at the Article 93[6], the depositor shall be the person bound by the declaration placing the goods under the customs entrepots procedure or to whom the rights and obligations of such a person have been transferred and customs warehouse means the place established for storing the goods that is under and by the supervision of the customs administrations and established under the conditions laid down in accordance with the regulations.

Therefore, it will not be wrong to rank the reasons for the existence of the customs warehouse regime as an economically effective customs regime as follows.

1. Not to pay customs taxes until the free movement of goods regime for imported goods is in place and stay out of trade policy measures,

2. To store an item that does not enter free circulation and is transitable to another country until transit without paying import taxes and without being subject to trade policy measures,

3. To store or handle import goods that have not entered the free circulation until the manufacturing or marketing stage,

4. To regard the exporting party as having been exported together with the receipt of the warehouse after the leaving of the customs territory of Turkey.

There are certain rules for the receipt, preservation and removal of customs duties into customs entrepots, since customs duties are open or closed places with certain conditions under which customs supervision is placed. Since the goods in the customs entrepots are under customs supervision, goods can be entered and exited under the supervision of customs officers and authorized customs brokers [7].

\section{Places that are considered to be Customs Entrepots:-}

In the 3rd paragraph of Article 93 of the Customs Code, the Customs Entrepots was established as a place for the protection of the customs under the supervision of customs and the conditions and qualities to be sought in its establishment were determined by the regulation [8]. According to the customs legislation, there are places that are automatically registered as customs without any further arrangement or process. Those are;

1. Fairs and exhibitions demostrating a non-free movement,

2. Duty-free shops (free shops) and warehouses,

3. Responsibility of the postal administration and enclosed spaces for placement of foreign branches under the customs supervision to be counted.

\section{Goods to be placed in customs entrepots:-}

Customs warehouses may be provided with all kinds of goods that can placed from customs entrepots that are not entitled to free movement of goods regime and export-related measures. However, customs administrations may introduce limitations and restrictions on goods to be placed in the warehouse in the direction of their legislation and practices [9]. Limitations and special arrangements may be brought about, in particular for flammable, explosive and dangerous goods for which they are involved, or for goods which require special enclosures and structures.

The Customs Regulation has been published in order to clarify the issues that will be regulated by the Regulation of the Customs Law No. 4458 and which will guide the implementation. In the Article 333 of the Customs Regulation, 
the goods in a customs entrepots can be transferred to a third party using a sales agreement, the following points are remarkable:

1. Goods stored in the customs warehouse can also be transferred to someone else by sale. The sale of solvent and base oil stored in the customs warehouse is not allowed if the take-over of the good is to be freely circulated by the transferee.

2. If there is a legal obstacle such as anticompetitive sequestration or a precautionary injunction in relation to the property of a contradiction, the procedure cannot be carried out without clarification.

3. The legal responsibilities related to the goods including customs duties and fines as well as the transfer of the athlete are passed to the acquirer and necessary amendments are made to the warehouse inventory records. In the event that the contestant is not subject to a customs approving new transaction or use within 5 working days, a new warehouse declaration will be issued by the transferee for the item in question. Documents related to the transfer transaction shall be submitted to the customs office during the issuance of the new customs approved transaction or use or the new warehouse declaration.

4. Requests relating to the devine of the contestant in the private warehouse shall be accepted on condition that they are approved in customs within five working days after the transfer of the contestant and that the warehouse is removed by a new process or use.

With the arrangement, it is stated that the goods stored in the customs entrepots may also be transferred to another person by sale and transfer procedures in the customs office are bound to the written notification condition; however, in some cases determined by the Undersecretariat, written notification condition is not required [10].

The Regulation on Transfer Procedures at the Customs Registry also states that: "In the event of any circumstance preventing the transfer of property, the transfer shall be completed by making the necessary changes in the warehouse inventory records in case the transfer request is deemed appropriate, will take over the relevant legal responsibilities ". In addition to this, "the request for take-over in the private warehouse shall be accepted on the condition that a new transaction customized to the customs within 5 working days after the transfer of the contestant or removal of the warehouse by the use is made".

Customs duties shall take over the legal responsibilities related to goods, including customs duties and monetary penalties together with the transfer of goods. In this case the corresponding warehouse has to make the necessary changes in the inventory records [11].

\section{Tax assesment of take-over operations in customs entrepots:-}

Within the scope of the customs entrepots regime, the income must obtained from the sale of these goods through the transfer of customs entrepots to Turkey and in the form of full taxpayer real persons and institutions that earn such income in Turkey shall be deemed to be obtained in Turkey and shall be deemed to be income tax or corporation tax must be included in the declaration.

On the other hand, for real persons with limited responsibility and institutions with limited responsibility, the earnings must be provided via a business or a permanent representative in Turkey for acquired earnings in question to be taxed in Turkey. In terms of the Value Added Tax, since the transfer of goods subject to customs entrepots from the entrepots is excluded from VAT, no additional VAT will be calculated due to sales from the entrepots [12]. The transfer of the goods located in customs warehouse is evaluated as normal sales transaction and recorded in the legal books and reflected in the declaration. In this case, it is necessary to comply with the provisions related to the invoice in the Tax Procedure Law No. 213 within the sales (transfer) bill to be arranged.

In accordance with the 3rd paragraph of Article 333 of the Customs Regulation, in case of transferring to the other party in the entrepots, the transferor shall notify the transferor of the date of the sale invoice to the customs office within 5 working days of customs application or a new entrepots declaration, Penalties shall be imposed in accordance with paragraph 1 of Article 241[13].

\section{Evaluation in terms of Corporate Tax:-}

In Article 3 of the Tax Act No: 5520; it is stipulated that the legal and business center in Turkey shall be taxed on the profits that it was obtained both in Turkey and outside of Turkey. 
In Article 6 of the Corporate Tax Law; It has been stated that the provisions on the commercial income of the income tax law will be applied in the determination of the net corporate income, which will be calculated on the net corporate income that the taxpayer obtained during the period of an accounting period.

In the General Communiqué of the Tax Procedures Code, which is 362 ranks; it is stated that the taxpayers holding books on the basis of the balance sheet have to report their purchases and sales of goods and services exceeding a certain amount (5000 TL) by form BA-BS forms.

In the General Communiqué of the Tax Procedure Law no. 396 [14], "all kinds of goods and / or services purchases and sales made within the limits specified by the taxpayers who are obliged to be notified, the documents related to them (invoices, self-employment receipts, customer receipts, expense compulsory, payment due to fuel pumps they will be included in the BA-BS forms regardless of whether they are a recorder device, an insurance commission expense companion, or a passenger ticket ").

As stated in the above-mentioned explanations, the sales made by transfer through Customs entries are to be included in the Corporate Tax Statement, so in case of the overdue stated in the blood of these sales, the BA-BS form must be notified.

\section{Evaluation in terms of Value Added Tax:-}

In the Article 1 of the Value Added Tax Law [15], it is stipulated that the import and export of all goods and services and the deliveries and services carried out in the framework of commercial, industrial, agricultural activities and self-employment activities in Turkey are subject to the Value Added Tax.

In the Article 6 of the Value Added Tax Law, the fact that the works are carried out in Turkey, that the goods are in Turkey at the time of delivery, that the service is carried out in Turkey or that the service is to be used in Turkey.

According to the Customs Regulation, depending on whether the sale transactions through customs entrepots in the Customs Warehouse are deemed to have taken place within the territory of the Republic of Turkey, the mentioned transactions are subject to taxation without discrimination of full or narrow taxpayer, private and official institutions. However, according to Article 16 entitled "Exemption for Importation", which is the exception to the Value Added Tax Law, the delivery of the goods in which the transit and customs entrepots regimes in the customs law and the temporary storage and free zone provisions are exempted from the Value Added Tax, has been exempted.

Moreover, the delivery of goods not yet nationalized, in customs parcel purchased abroad is also exempted from the Value Added Tax.

\section{Conclusion:-}

The customs entrepots is a commercial operation that often involves the sale of goods or commodities imported domestically or abroad. The sale of goods abroad is considered as a transit trade transaction. Domestic sales of the same goods are treated as ordinary sales. Institutions Tax According to the Law; since the taxpayers' subject institutions are subject to taxation on the basis of both the domestic and foreign earnings, the corporate profits are included in the values obtained from the sales carried out in the customs office. As regards Value Added Tax, the transaction is deemed to have occurred in Turkey since the customs entrepots are located in the territory of the Republic of Turkey. In addition, imports of goods and services are also included in the scope of the Value Added Tax. However, while the sale transaction through the customs office is entered into the Value Added Tax issue, it is exempted from the Value Added Tax according to the Article 16 of the import section Value Added Tax.

\section{References:-}

1. WTO (World Trade Organization), 2014. WTO Agreement on Trade Facilitation: Self-Assessment Guide. WTO, Geneva.

2. Niepmann, Friederike and Tim Schmidt-Eisenlohr, 2013, iInternational Trade, Risk and the Role of Banks,îFederal Reserve Bank of New York Sta§ Reports, 633.

3. Customs Law No. 4458, R.G. Date: 4/11/1999 N: 23866

4. Customs Law No. 4458, R.G. Date: 4/11/1999 N: 23866

5. Customs Legislation 
6. Serkan Kurt, "Assesment of take-over operations in customs entrepots in terms of corporate tax and VAT Laws", Vergi Raporu Dergisi, October 2107.

7. Önal Yilmaz, "Explanations on the customs entrepots regime", LojiMakale, 6.12.2016

8. Mehmet MollaisMailoğlu, "Tax status of the goods sold in the warehouse", 12 May 2016, www.mollaismailoglu.com/genel/antrepolarda-satılan-mallların-vergisel-durumu/

9. Customs Law No. 4458, R.G. Date: 4/11/1999 N: 23866

10. Ministry of Customs and Trade, "Customs entrepots regime" Circular numbered 10 and 2000

11. Ufuk Özdemir, "Customs entrepots regime, hand-held goods change in warehouse, VAT", 18 August 2011, www. muhasebetr.com/yazarlarimiz/ufuk/057.

12. Musa Yıldırım, Mustafa Taşkıran, "Taxation of the profits gained from sale of warehouses subject to customs bonded warehouse regime by sale of warehouse period", Tax problems magazine, march 2013, sssue 294

13. Hasan Akdogan, "Responsibility in the transfer of articles in antrepresentation", world newspaper, 4th May. 2017

14. 396 VUK General Communiqué, OG. Release date 04.04.2010, S.27483

15. Corporation Tax Law, R.Gazzette : Date: $21 / 6 / 2006$, N: 26205

16. Value Added Tax Law, R.Gazette Date : 2/11/1984, N : 18563 